4. Медведь В.И. Метаболический синдром: взгляд терапевта. Медицинские аспекты здоровья женщины. 2017. № 3. С. 14-19.

5. Cahill AG, Haire-Joshu D, Cade WT. Weight Control Program and Gestational Weight Gain in Disadvantaged Women with Overweight or Obesity: A Randomized Clinical Trial. Obesity (Silver Spring). 2018. № 26(3). P. 485-491.

6. Вдовиченко С.Ю., Фахрутдінова Т.Д. Профілактика акушерської та перинатальної патології у жінок з надмірним збільшенням маси тіла під час вагітності. Здоровье женщиныл. 2018. № 3 (129). С. 77-79.

DOI https://doi.org/10.30525/978-9934-26-075-9-26

\title{
ОЦІНКА ЕФЕКТИВНОСТІ ЛІОФІЛІЗОВАНИХ КСЕНОДЕРМОІМПЛАНТАТІВ НАСИЧЕНИХ НАНОКРИСТАЛАМИ СРІБЛА В МІСЦЕВОМУ ЛІКУВАННІ ХВОРИХ $З$ ПОВЕРХНЕВИМИ ОПІКОВИМИ РАНАМИ
}

\author{
Тузюк Н. В. \\ лікар комбустіолог \\ КНП «8-а міська клінічна лікарня м. Львів» \\ м. Львів, Украӥна
}

Актуальність. Сьогодні $\epsilon$ актуальними питання пошуку нових покривів для лікування ран. В світовій медичній практиці є більше 2000 замінників шкіри, які використовуються для місцевого лікування ран в різних країнах світу, кожен 3 них має свої переваги і недоліки і всі вони $\epsilon$ тимчасовими. Сучасне місцеве лікування опіків має включати в себе застосування активних пов'язок, яким властива протимікробна, протизапальна і стимулююча епітелізацію шкіри функція.

Мета: Метою цього дослідження була оцінка ефективності пов'язки ксенодермоімплантатів насичених нанокристалами для місцевого лікування хворих 3 поверхневими опіками, та покращення результатів лікування пацієнтів 3 поверхневими опіками I-II А ступеня, які лікувалися в Львівському центрі термічної травми та пластичної хірургії.

Матеріали і методи: Матеріалом для дослідження стали 58 хворих віком від 18 до 65 років 3 опіками I - IIA- ст. загальною площею від 3\% до 40\% поверхні тіла, у яких для місцевого лікування застосовували ліофілізовані ксенодермоімплантати, які перед накладанням на рану насичували нанокристалами срібла за нашою методикою (Патент України на винахід №111557) . Пацієнти чоловічої статі - 51.8\% 
від усіх обстежуваних, а пацієнти жіночої статі - 48.2 \% обстежуваних. Опікові рани займали різні ділянки тіла. Час, що минув від моменту отримання опіку до використання пов'язки і початку спостереження коливався у межах від 1 години до 5 днів. Контрольну група становили 38 пацієнтів у лікуванні яких використовували розчини антисептиків (бетадин, хлоргекседин, декасан), мазі левомеколь, офлокаїн, бепантин.

\section{Отримані результати та обговорення.}

Протягом останніх десятиліть у лікуванні опіків класичними препаратами, що містили срібло були: нітрат срібла. Широко застосовується для лікування опікових ран у вигляді $0,5 \%$ розчин нітрату срібла. Нітрат срібла у розчинах $0,5-1 \%$ діє на бактерії грам $(-$ та +$)$, не викликає алергічних реакцій та болю. Однак використання цього препарату $\epsilon$ трудомістким, його треба застосовувати $2-3$ рази на добу, або змочувати рану кожні 2 години. В кінці $60-$ х років минулого століття був створений крем сульфадіазин срібла, який зробив революцію в лікуванні хворих 3 поверхневими опіковими ранами. Але цей препарат має іонне срібло відносно короткої дії, і застосування його вимагає частої зміни пов'язки. Однак препарат не проникає крізь струп. Срібло є біологічно активним, коли воно знаходиться в розчинній формі, тобто як $\mathrm{Ag}+($ іони $)$ або наночастинки (AgO). Нанесення нанокристалічного срібла на ліофілізований ксенолермоімплантат дозволило нам використовувати останній, як тимчасове покриття для лікування хворих 3 опіками I-IIA ст. Ксенодермоімплантат накладали безпосередньо на рану попередньо очищену скальпелем, промиту фізрозчином та оброблену антисептиком (розчин бетадину). Пов'язку накладали, переважно захоплюючи кількасантиметровий фрагмент здорової ділянки шкіри. При накладанні ксеноімплантат приклеюється до опікової поверхні і не змінюється протягом 3-4 діб, а інколи 6-7 діб. Оцінка ефективності ліофілізованих ксенодермоімплантатів насичених нанокристалами срібла проводилася на підставі результатів клінічних спостережень і лабораторних досліджень. Поверхневі опіки I-IIА становили 34 хворих (58.6\%), опіки IIA ст. 24 хворих (34.5\%) У чотирьох пацієнтів (6.9\%) з дослідної групи діагностовано клінічні симптоми інфікування рани до початку лікування пов'язкою через пізне поступлення в стаціонар (5-й день). Рани 3 незначною кількістю виділень становили $37.9 \%$, 3 помірною кількістю $32.7 \%$, а з великою кількістю виділень $29.4 \%$ від усіх обстежуваних. У контрольній групі пацієнтів проводилося лікування ран з використанням розчинів антисептиків та мазей. Після очищення рани накладали на поверхню мазь левомеколь, офлокаїн та марлеву пов'язку з розчином антисептика (бетадин, декасан). Оцінювали та аналізували наступні фактори: атравматичність накладання (аплікації) пов'язки на рані, iii здатність поглинати виділення, легкість усунення пов'язки (оцінювали за 
шкалою зростання: низька-помірна-добра- дуже, добра), а також суб'єктивну оцінку пацієнтом болючості рани і наявністю больових відчуттів під час усунення пов'язки (больові відчуття: відсутні-незначнісередні-сильні), а також комфортність у щоденному функціонуванні 3 пов’язкою (низька-помірна-добра-дуже добра).

Таблиця 1

\section{Оцінка ефективності ксенодермоімплантатів насичених}

нанокристалами срібла

\begin{tabular}{|c|c|c|c|c|c|c|}
\hline & $\begin{array}{c}\text { Аплік } \\
\text { ація } \\
\text { вані } \\
\text { риділення }\end{array}$ & $\begin{array}{c}\text { Біль } \\
\text { глинання } \\
\text { вніманні }\end{array}$ & $\begin{array}{c}\text { Біль при } \\
\text { Ком- } \\
\text { форт }\end{array}$ & $\begin{array}{c}\text { Простота } \\
\text { вида- } \\
\text { лення } \\
\text { пов'язки }\end{array}$ \\
\hline $\begin{array}{c}\text { Дуже } \\
\text { добра(сильна) }\end{array}$ & 65.5 & 15.1 & 75.9 & 5.2 & 72.5 & 87.9 \\
\hline $\begin{array}{c}\text { Добра } \\
\text { (середня) }\end{array}$ & 31.1 & 29.3 & 20.7 & 10.3 & 27.5 & 12.1 \\
\hline $\begin{array}{c}\text { Помірна } \\
\text { (незначні) }\end{array}$ & 3.6 & 29.3 & 3.4 & 12.0 & 0 & 0 \\
\hline $\begin{array}{c}\text { Низька } \\
\text { відсутні) }\end{array}$ & 0 & 20.3 & 0 & 72.5 & 0 & 0 \\
\hline
\end{tabular}

Таблиця 2

Оцінка ефективності застосування пов'язок

з антисептиками та мазями.

\begin{tabular}{|c|c|c|c|c|c|c|}
\hline & $\begin{array}{c}\text { Апліка- } \\
\text { ція }\end{array}$ & $\begin{array}{c}\text { Біль в } \\
\text { рані }\end{array}$ & $\begin{array}{c}\text { Поглина } \\
\text {-ння } \\
\text { виділенн } \\
\text { я }\end{array}$ & $\begin{array}{c}\text { Біль } \\
\text { при } \\
\text { зніман } \\
\text { ні }\end{array}$ & $\begin{array}{c}\text { Комфор } \\
\text { т }\end{array}$ & $\begin{array}{c}\text { Простот } \\
\text { а } \\
\text { видален- } \\
\text { ня }\end{array}$ \\
\hline & $\%$ & $\%$ & $\%$ & $\%$ & $\%$ & $\%$ \\
\hline $\begin{array}{c}\text { Дуже добра } \\
\text { (сильна) }\end{array}$ & 76.3 & 71.1 & 50 & 0 & 12.6 & 0 \\
\hline $\begin{array}{c}\text { Добра } \\
\text { (середня) }\end{array}$ & 23.1 & 23.7 & 25 & 5.3 & 7.9 & 10.5 \\
\hline $\begin{array}{c}\text { Помірна } \\
\text { (незначні) }\end{array}$ & 0.6 & 5.2 & 25 & 0 & 10.5 & 79 \\
\hline $\begin{array}{c}\text { Низька } \\
\text { (відсутні) }\end{array}$ & 0 & 0 & 0 & 94.7 & 79 & 0 \\
\hline
\end{tabular}


Таблиця 3

\section{Терміни епітелізації ран у хворих 3 поверневими опіковими ранами.}

\begin{tabular}{|c|c|c|}
\hline \multirow{2}{*}{1} & $\begin{array}{c}\text { Лікування ран пов'язками } \\
\text { ліофілізованими } \\
\text { ксенодермоімплантатами } \\
\text { насиченими нанокристалами } \\
\text { срібла (ліжко днів) }\end{array}$ & $\begin{array}{c}\text { Лікування ран } \\
\text { альтернативними методами } \\
\text { (ліжко днів) }\end{array}$ \\
\hline 2 & 13.8 & 16.4 \\
\hline
\end{tabular}

Висновки 1. Власні спостереження дають можливість зробити перші позитивні висновки, що свідчить про високу ефективність пов'язки ліофілізованих ксенодермоімплантатів насичених нанокристалами срібла у лікуванні хворих з опіковими ранами I-II А ступеня.

2. Показанням для застосування пов'язки є опікові рани 3 добрим прогнозом щодо самостійного загоювання з добрим функціональним та косметичним ефектом у короткі терміни.

\section{Література:}

1. Коваленко А.О., Коваленко О. М., Козинець Г. П.. Оптимізація хірургічного лікування постраждалих 3 поверхневими та глибокими дермальними опіками. Хірургія України. 2018. № 2. С. 75-79.

2. Коваленко О. М., Козинець Г. П.,. Коваленко А. О. Вибір ранових покриттів при лікуванні поверхневих опіків. Клінічна хірургія. 2015. № 11.2. С. $58-59$.

3. Kovalenko O. M.. Kozinets G. P Kovalenko A. O. Our experience of treating superficial dermal burn wounds with foam dressings. 28 Conference of European wound management association. Krakow, Poland. 9-11 May 2018. P. 92.

4. Wilkinson L.J. Silver and nanoparticles of silver in wound dressings: a review of efficacy and safety / L.J. Wilkinson, R.J. White, J.K. Chipman, Journ. of woundcare. - 2011. 20. № 11. P. 543-549

5. Trop M., Novak M., Rodl S. et al. Silver-coated dressing acticoat caused raised liver enzymes and argyria-like symptoms in burn patient. J Trauma. 2006. 60.1. P. 648-652. 